\title{
The Influence of internet environment on the career development of college English teacher
}

\author{
Guo Zhe \\ Foreign Language College of BeiHua University, Jilin, China
}

\begin{abstract}
Keywords: Internet environment; College English teachers; Career development
\end{abstract}
\begin{abstract}
Under the background of economic globalization, the emergence of all kinds of new media teaching means relying on the internet has promoted the transformation of the teaching mode and the reform and innovation of teaching content. Nowadays, all walks of life give higher expectations to teacher, which gets the career development of teachers into trouble. Under this background, it urgently needs to solve how college English teachers deal with the complex situation they face at present. This paper firstly introduces the influence of economic globalization in the internet era on higher education, and then analyzes the current situation of college teachers' career development and figures out the probable influencing factors, and finally explores the way out of the current troubles in career development for college English teacher, hoping to promote the long-term development of college English teacher.
\end{abstract}

\section{Introduction}

Economic globalization trend is more and more obvious with the emergence of a large number of advanced technology quickly permeating into every field of society. In the era of information, international cultural exchanges, active communication and higher education globalization are the mainstream of contemporary development, which are attached great importance to by the scholars from each country in the world. Under this background, college English teachers suffer from a bottleneck in their career development. In addition to facing a major crisis in specialty, they also suffer a survival crisis. Therefore, college English teachers should foster a sense of crisis effectively, strengthen the professional learning and improve the professional level, use reasonable means to carry out scientific research and actively explore new development path. Only in this way, college English teachers won't drown silently in the army of vocational competition and get rid of the fate of being eliminated by the times.

\section{The influence of the internet environment on higher education}

With the rapid development of economy, especially after our country ascending as one of the members in the World Trade Organization (WTO), it has a great influence on almost every field. Also, it brings certain changes in the field of higher education and gradually speeds up the internationalization process of higher education. For higher education undertakes the duty of manufacturing and spreading cultural knowledge and cultivating talents for the construction of the society. Therefore, under the globalization background, higher education becomes more prominent and important. Internationalization has become the basic direction and trend of current and future development of higher education. In the internationalization trend, Chinese government has introduced a series of preferential policies, which greatly promotes and stimulates the international 
exchange and strengthens the international cooperation.

International education is experiencing a rapid rise and growing and expanding unceasingly. Internationalization of education refers to the integration of higher education with international level as far as possible on the basis of reserving national fundamental education characteristics at the same time and the change of talent cultivation mode to become an international model. In addition, the teaching level and education background of college teachers also should meet the national standard.

Exactly, the internationalization of education is embodied in the following content: the rapid increase of international education exchange activities, the vigorous development of education for studying abroad, more attention to foreign language education, mushroom development of international cooperation teaching, rapidly speeding up of the internationalization of education, of which the most evident in the higher education is the rapidly speeding up of the internationalization of education.

At present, the unification and standardization of education mode are to ridicule. It is to distort the nature of education to require students to be educated with the unified teaching material and accept unified teaching content because students are born to be different in their personalities. Big data education provides us with the possibility of a variety of options: flexible educational system, flipped classroom, on-demand learning, lifelong learning and so on. These education modes enable learning not to be restricted by the objective conditions of time, place and space. MOOC appears to make students have access to high quality of higher education, in which students can choose what to learn, how to learn and what time to learn. In the big data era, education doesn't refer to online education and distance education and it is not simply transferring classroom teaching to internet education on the internet, but emphasizes that education should get rid of industrialization and become a data supporting behavioral science.

With the advent of the era of internet big data, the teaching model of college English will experience a radical change. With the rich network resources, students can use mobile devices to access to information anytime and anywhere and involve into autonomous learning of word and grammar knowledge. The status of traditional face-to-face teaching is being challenged and the teacher in traditional English class is no longer the only owner of authoritative information. College English classroom teaching valuing students' passive acceptance as orientation will inevitably decline. Education workers must be aware of such change, so they must timely adjust their role and make reasonable plan for their career development so as to save for a rainy day,.

\section{The current career development situation of college English teachers}

Under the background of globalization, when there is a higher internationalization of college English education, there will be a more apparent popular trend in the whole society. English will gradually develop towards the international level. The internationalization of English also points out the way of teaching reform correspondingly. Since there is a long way to go in the future, it at the same time makes English teachers' career development face an unprecedented dilemma and an intractable crisis.

(1)Specialty crisis

From the scientific research level, compared with professional teachers, college English teachers are stuck in the lagging situation due to the lack of specific direction of specialty. From the characteristics of specialty, college English teaching doesn't refer to the category of linguistics, which naturally does not belong to the field of pedagogy. However, there is a certain correlation between college English teaching and pedagogy. Scholars at home and abroad have spent much 
time exploring the basic attributes of foreign language teaching and have summed up some viewpoints. Compared with senior subjects, however, it is not hard to find that college English is relatively independent. In other words, it is sui generis, but its theoretical system construction is in a great deficiency. At present, the teaching research activities of college English education mainly strand in the primary stage, having a strong dependence on the foreign experience and lacking of theoretical research results, which has resulted in a lack of solid theoretical support in the concrete teaching activity.

(2) Survival crisis

With the gradual practice of the internationalization trend step by step, for higher education, college English teachers are stuck in development bottleneck and suffer from a huge survival crisis. Private training institutions are emerging like mushrooms and college students are more in favor of such institutions. Broad, superior and vibrant education market also attracts the attention of foreign teachers and they pour into the domestic education market. In addition, overseas returnees constitute a great threat to college English teachers and make them face a serious survival crisis.

\section{The factors influencing career development}

(1) Successive promulgation of reform systems

College employment system is not sound for a long time, such as the immature talent selection system, the unreasonable procedures, the unstrict inspection system and the shortage of elimination mechanism. What's more, most college English teachers do not have crisis consciousness or have weak crisis consciousness, so they remain stagnant in the concrete teaching, make little improvement and greatly reduce the quality of college English teaching. In 2002, the State Council forwarded the relevant employment system and various provinces and cities also enacted local employment systems continually. Most of them carry out the principle of evaluating staff and adjusting salary on their performance, which has a huge impact on the so-called "iron rice bowl system” in the past and significantly improves college English teachers' sense of anxiety.

(2)Mushroom emergence of non-government training institutions

Foreign teachers massively flock into non-government training institutions like New Oriental and Cambridge English throughout various provinces and cities. These training institutions include students at all ages to the scope of training. The development of New Oriental is the most prominent and receives the vast majority of parents and students' recognition. Under the background of exam-oriented teaching, students' learning has a distinct practical characteristic and most students equate English learning to grade examination, so enter for the exam-oriented training institutions, leading to the lack of attraction of college English teaching. The impact of financial crisis enables a large part of the foreign teachers with TESOL certificate to emerge into domestic education market and compete with college English teachers by virtue of their native language advantage, making college English teachers face a serious crisis in career development.

(3) Common occurrence of domestic bilingual talents

Bilingual talent refers to those who have superior ability in English language use with non-English major education background, use original English textbooks flexibly and open specialized courses in English language, so they belong to the interdisciplinary talents. This kind of teaching mode can fully integrate English language and specialized teaching, mobilize students' learning enthusiasm and improve their interest in English learning. Most of the current domestic colleges have already started to apply the teaching mode, which is worth pondering for English teachers regarding basic English as the core and helps them how to improve their professional level 
and make it meet the demand of domestic bilingual talent constantly.

\section{Postsecondary pathways of career development}

The big data of internet era posters a great challenge to teachers in the aspects of professional function, teaching design and teaching evaluation and so on. How should college English teachers deal with these challenges? Basically, college English teachers must pay attention to self-development, acquire education knowledge and skills through lifelong learning and become a foreign language teacher that can meet the needs of social development and talent training. When it comes to teachers' self-development, we firstly must be clear of the concept of "teacher development”. For this concept, Lanze expounded in general: teacher development is a process of sustainable development in intelligence, experience and attitude. Crandall further pointed out that teacher development is a lifelong process of growing that contains the collective or individual autonomous learning. The "self-development of teachers" puts more emphasis on the personal autonomy of teachers. Peng Huiling thought thatteachers' self-development refers to gaining personal growth through their own efforts.

Their own efforts include studying theoretical knowledge, attending the related training, independent teaching reflection and taking action to solve problems in the process of teaching, etc. Personal growth is characterized by the improvement of teachers' own quality so as to promote the improvement of teachers' teaching and scientific research level. 2013 is a year which is generally considered as the first year of the era of "big data". However, there are still many teachers lack of awareness about the new concept, unclear the effect of big data on college English teaching and lack of crisis consciousness. In fact, the deepening of China's college English teaching reform and the advent of the Internet era of big data endow the teachers' self-development with new meaning, and teachers have to constantly develop themselves to keep pace with times and realize the sustainable development of teaching and scientific research through gaining lifelong learning ability.

(1) Renew concept and foster a sense of crisis

At present, under the background of globalization and internationalization in the higher education, domestic education vigorously promotes the reform of education and makes college English teachers experience career and survival crisis and face career development challenges. To effectively get rid of the crisis and face the challenge successfully, college English teachers must update education concept, actively learn modern education idea and set up crisis consciousness, thus, they are able to realize a long-term development in teaching career. In addition, they should also form the consciousness of lifelong learning, constantly enhance their professional knowledge, actively explore foreign language education theory, systematically study foreign language education method, so as to improve sense of responsibility, strengthen crisis consciousness and promote professional development.

(2) Increase the professional depth and expand the study scope

Under the background of globalization, institutions of higher education are developing towards the direction of the internationalization gradually and the demand of professional English talents is also increasing rapidly. More and more scholars advocate and support to highlight the teaching ideas with the help of English professional information. Most colleges and universities begin promoting bilingual teaching and vigorously apply across-curriculum teaching, which requires college English teachers to continue to increase their professional depth and actively expand the scope of study.

There is a broad research scope of foreign language teaching, including psychology, education 
theory and social communication, etc. Therefore, college English teachers should clear the research direction, reasonably choose research field, carry out in-depth exploration and careful observation and finally achieve the goal of expanding research field and increasing the depth of specialty. That is to say, college English teachers need to timely record the concrete teaching process, discover problems and use big data analysis to seek solutions based on their own teaching practice.

On the other hand, with the diversification of English learning approach, students' expectation to college English classroom differs in two extremes. College English teachers should be based on the data analysis, improve teaching mode and enable students to gain knowledge in class. The famous educationist in China Lu Youquan once pointed out that in the present situation with increasing modernization of education technology, if college fails to edify their students in terms of scientific spirit, democratic spirit, critical spirit and ideal personality, it is unnecessary for students to attend college. College English teaching should take it as the core to cultivate students' critical thinking in order to improve the students' comprehensive language application ability, build a new classroom teaching mode and empower students to fish.

(3) Master modern information education technology, possess the ability to integrate English learning resources and carry out individualized teaching

In the modern age, big data is playing an increasingly important role in knowledge dissemination and becomes a strong competitor of school teachers. It is supposed that in the near future everyone can gain a large number of high-quality courses through installing the software on mobile devices in the network and study easily and conveniently anytime and anywhere. In order to avoid the loss of students and even course, college English teachers must firstly use modern information education technology to arm themselves and guide students to make full use of the rich resources of the network information platform. Everything has two sides. What big data brings to students is a big problem of information overload. In the era with infinitely broad application of network technology, students are also faced with pressure brought out by overloaded data and information, but it is quite difficult for the students to clear out how to search and screen useful information. This requires college English teachers to change their roles from a small amount of information provider to a large number of resources integrator. They are supposed to widely collect all kinds of scattered resources about learning information through analysis and processing and then selectively provide the effective information to students in the form of multimedia and network so as to guide students

(4)Improve education background and enhance professional ability

College English teachers should possess solid discipline knowledge, have strong professional ability and constantly enhance their level of education. At the same time, college English teachers should have the courage to break through themselves and strengthen their comprehensive ability such as teaching ability, scientific research ability and self-reflection ability. Self-reflection ability can spur teachers to make positive thinking of education value, organize in-depth education practice and systematically study education problems so as to improve college English teachers' sensitivity, strengthen scientific research quality and opening the path of teaching work.

\section{Conclusion}

Internet big data era has come, so, multiple sites across the country are advancing the education informatization: setting up the pilot school of digital learning, carrying out researches on flipped classroom, developing micro courses and organizing face-to-face English teaching practice. These researches and practices make college English teaching mode change gradually and college English teaching has presented its diversification characteristic in the era of big data. In this context, college 
English teachers' roles and functions have been facing unprecedented challenges. College English teachers must be provided with corresponding anticipation ability in the application of teaching concepts, education technology and discipline, adhere to unceasing self-development and chug along in the tide of education.

\section{Reference}

[1] Jiang Yumei. College English teachers' professional development present situation and influence factors analysis [J]. Foreign Languages in China, 2012(4):17-19

[2] Lange, D .A blue print for a teacher development program [A. In J. C. Richard \& D. Numan. Second Language Teacher Education [C. C am bridge: Cam bridge University Press, 1990.

[3]Zhu Shuhua, Wang Dandan. Self-orientation and development analysis of college English teachers in the era of transformation[J]. Education and Career, 2012(9):88-89

[4]Peng Huiling. Introduction to the external support for college English teachers' self development [J]. Education and Career, 2011(8):72-74.

[5] Crandall, Joann. Language teacher educatio [ J ] . Annual Review of Applied Linguistics, C am bridge: Cam bridge University Press, 2000. 